\title{
Beklenen ve Beklenmeyen Para Politikası Kararlarının Hisse Senetleri Fiyatları Üzerindeki Etkileri ${ }^{1}$
}

\author{
The Effect of Expected and Unexpected Monetary Policy Decisions on \\ Stock Prices
}

Bekir Tamer GÖKALP2

Geliş tarihi: 25.05.2016, Kabul tarihi: 31.01.2017, Basım tarihi: 10.06.2017

\section{Özet}

Para politikası kararlarının hisse senetlerinin fiyatları üzerinde etkili olduğuna dair çok sayıda çalışma bulunmaktadır. Ancak Türkiye'de beklenen ve beklenmeyen para politikası kararlarının hisse senedi piyasasına ilişkin bir herhangi bir çalışma mevcut değildir. Bu amaçla bu çalışmada Edelberg ve Marshall (1996) tarafindan analiz edilen çalışmayı takiben para politikası faiz kararları, beklenen ve beklenmeyen para politikası kararları şeklinde ayrıştırılarak hisse senetleri fiyatları üzerindeki etkileri incelenmiştir. En küçük kareler yöntemi ile yapılan analizden elde edilen bulgular hem beklenen hem de beklenmeyen faiz kararlarının hisse senetlerinin getirisini yakından etkilediğini göstermiş, beklenmeyen faiz kararlarının etkisi beklenene kıyasla daha yüksek bulunmuştur. Bu bulgu Türkiye'de rasyonel bekleyişler hipotezinin hisse senedi piyasasında tam olarak geçerli olmadığını, insanların kısmen de olsa rasyonel karar verdiklerini ancak sürprizler karşısında çok da yapacak birşeyleri olmadığını göstermiştir.

Anahtar Kelimeler: Beklenmeyen Para Politikasi, Beklenen Para Politikasi, Hisse Senedi Piyasası, EKK

JEL Kodlar: E52, G12, G18

\begin{abstract}
There are lots of studies accept that the monetary policy decisions have effects on stock prices. But there is no any work on Turkish economy that focusing on expected and unexpected monetary policy decisions on stock prices. In this regard, following Edelberg and Marshall (1996) we decomposed monetary policy interest rate decisions as expected and unexpected monetary policy decisions and investigated the effect of them on stock prices. The findings from ordinary least squares method showed that both expected and unexpected interest rate decisions have closely impacts on return of stocks. Moreover, the effects of the unexpected decisions have greater impacts on the expected ones. This finding implies that the rational

\footnotetext{
${ }^{1}$ Bu çalışma, "Türkiye'de Asimetrik Faiz Koridoru Uygulamasinin Hisse Senedi Piyasasindaki Alternatif Serilerin Getirileri Üzerindeki Etkileri" isimli doktora tezinden türetilmiştir.

2 Odeabank A.Ş, Müdür Yardımcısı, Dr.

bt.gokalp@gmail.com
} 
expectations hypothesis is not completely valid in stock markets and economic agents' decisions are only partly rational and they have nothing to do when there is some surprises.

Key Words: Unexpected Moenatary Policy, Expected Monetary Policy, Stock Markets, OLS

JEL Codes: E52, G12, G18

\section{Giriş}

Finansal piyasalar para politikası kararlarından çok hızlı bir şekilde etkilenme potansiyeline sahiptir. Bu nedenle finansal veriler, para politikasının anlık etkilerini gözlemleyebilmek için son derece önemlidir. Finansal veriler içerisinde yer alan varlık fryatları gerek ekonominin parasal kesiminin davranışının izlenmesi, gerekse de ekonominin reel kesiminde meydana gelen değişimlerin izlenmesi açısından oldukça yararlı bilgiler sunmaktadır. Varlık fiyatları arasında hisse senedi fiyatları genellikle en yakından izlenebilen ve ekonomik haberlere en hılı tepki veren verilerden olması sebebiyle birçok araştırmaya konu olmuştur.

Bernanke ve Kuttner (2005) para politikası kararları ile hisse senedi fiyatları arasındaki ilişkiyi belirlerken beklenen politika davranışlarının yatırımcıların kararlarında zaten yer aldıklarını belirtmişlerdir. $\mathrm{Bu}$ nedenle yazarlar para politikasının etkisinin beklenen ve beklenmeyen olmak üzere ikiye ayrilarak incelenmesinin, yatırım kararlarının anlaşılması açısından önemli olduğunu vurgulamışlardır. Bredin ve diğerleri (2007) tarafindan yapılan çalışmada da benzer bir yaklaşım benimsenmiş ve beklenmeyen politika değişikliklerinin hem toplam hem de sektörel hisse senedi serileri üzerinde önemli etkilerinin olduğu tespit edilmiştir.

Türkiye Cumhuriyet Merkez Bankası (TCMB), para politikası araçlarının yanısıra 2001 yılında bağımsızlığını kazandı̆̆1 günden bu yana yaptığ1 açıklamalarla ekonomiye geçmişe nazaran daha fazla yön vermektedir. Bu amaca uygun olarak gerçekleştirilen periyodik yayınlar, ekonomik birimlerin beklentilerini şekillendirmede önemli rol oynamaktadır. TCMB her ne kadar izlediği politikanın beklenen olmasına özen gösterse de piyasadaki beklentilerin gerçekleşen değerlerden farklılık arz etmesi, beklenmeyen politikaların da ortaya çıkmasına neden olmaktadır. Yapılan çalışmalar, beklenmeyen politikaların ekonomi üzerinde tahrip edici etkisinin beklenen politikalara nazaran daha fazla olduğunu göstermektedir.

TCMB'nin izlediği politikaların para piyasasının yanında varlık piyasası üzerinde de önemli etkileri vardır. Para politikasının varlık piyasası üzerindeki etkisinin anlaşılması, ekonomi yönetiminin başarısının anlaşılabilmesi açısından son derece önemlidir. TCMB tarafından alınan bir kararın etkisinin varlık fiyatlarına yansıyabilme hızı, büyüklüğü ve yönü, politikanın başarısının 
bir göstergesi olarak değerlendirilebilir. Bu nedenle bu çalışma TCMB tarafindan izlenen para politikasının etkilerinin analiz edilebilmesi açısından son derece önemlidir.

$\mathrm{Bu}$ çalışmada TCMB'nin beklenen ve beklenmeyen para politikası kararlarının Borsa İstanbul'da (BIST) işlem gören hisse senetlerinin fiyatları üzerindeki etkileri incelenecektir. Para politikası şokları Para Politikası Kurulu (PPK) toplantısının hemen sonrasında üç aylık Türk lirası LIBOR gelecek sözleşmelerindeki değișikliklerden türetilmiştir. Örneklem dönemi Ocak 2005 - Aralık 2015 tarihlerini kapsamaktadır. Else edilen bulgular küresel finansal kriz dikkate alındığında hisse senedi piyasasının para politikası şoklarına verdiği tepkide önemli değişiklikler ortaya çıktığını göstermiştir.

\section{Teorik Çerçeve}

Para politikasının hisse senedi piyasası üzerindeki etkisini açılamaya ilişkin geçmişten bugüne çok sayıda çalışma yapılmış ve çalışmalarda çok değişik modeller kullanılmıstır. Bu çalışmaları çeşitli biçimlerde gruplandırmak mümkündür. Ancak bizim çalışmamız açısından literatürdeki çalışmaların iki alt başlıkta toplanmasının daha uygun olacağı düşünülmüsstür: para politikası kararlarının hisse senetlerinin getiri oranları üzerindeki etkisi ve beklenmeyen (sürpriz) para politikası kararlarının hisse senetlerinin getiri oranları üzerindeki etkisi.

\subsection{Para Politikası Kararlarının Hisse Senetlerinin Getiri Oranları Üzerindeki Etkisi}

Para politikası kararlarının hisse senetlerinin getiri oranları üzerindeki etkisini inceleyen çok sayıda çalışma bulunmaktadır. Cook ve Hahn (1989), 1974 ve 1979 yılları arasinda Fed'in federal fon oranlarının oranlarında meydana gelen değişikliklerin hisse senetleri fiyatları üzerindeki etkileri incelemiş, çalışma sonucunda iki değişken arasındaki ilişkinin beklendiği gibi negatif değer aldığı bulgusuna rastlamışlardır. Bu durum merkez bankası tarafindan politika faiz oranı artırıldığında (azaltıldığında), hisse senedi piyasasında işlem gören hisse senetlerinin fiyatlarının düştüğü (arttığı) anlamına gelmektedir. aynı örneklem dönemini kapsayan bir diğer çalışma Roley ve Sellon (1995) tarafindan gerçekleştirilmiş ancak çalışma sonucunda iki değişken arasındaki ilişkinin daha zayıf olduğu bulgusuna rastlanmıştır. Zayıflamanın gerekçesi olarak alternatif varlıklardan tahvillerin getirisinin daha yüksek olması gösterilmiştir.

Yukarıdaki çalışmalardan farklı olarak Fair (2006) konuyu tersten analiz etmiş ve para politikasının ABD'de hisse senedi fiyatlarındaki etkisini incelemiştir. Çalş̧ma sonucunda elde edilen bulgular hisse senedi piyasasında meydana gelen hızlı ve ani fiyat değişimlerinin üçte bir gibi bir oranının para politikası kararlarından etkilendiğini göstermiştir. Radecki ve Reinhard (1994) 
tarafindan yapılan çalışmada da hisse senedi fiyatları ile faiz oranları arasındaki ilişkinin zayıfladığı bulgusuna rastlanmıştır. Bu bulgu her ne kadar para politikasının varlık piyasası üzerindeki etkisinin zayıfladığı anlamına gelse de iki piyasa arasında bağın halen güçlü olduğu çalışsmada ayrıca belirtilmiştir.

Boyd, Jagannathan ve Hu (2001) tarafindan gerçekleştirilen çalışmada hisse senetlerinin sadece para politikası kararlarına değil, aynı zamanda para politikası kararlarına ilişkin beklentilere de tepki verebileceğini iddia etmiştir. $\mathrm{Bu}$ amaçla merkez bankalarının para politikası kararlarını etkileyebilecek gelişmeleri iyi haberler ve kötü haberler olarak ayrı ayrı ele almışlardır. İyi haber olarak işsizlik oranlarının düşmesini, kötü haber olarak ise işsizlik oranlarının artmasını kullanmışlardır. Buna göre ekonomide işsizlik oranlarının düşmesi, ilerleyen dönemdeki para politikası toplantılarında faiz oranlarının düşme ihtimalini doğurmaktadır. Bu da faiz oranlarına ilişkin beklentileri değiştireceği için hisse senedi piyasasını da etkileme ihtimali mevcuttur. Bu nedenle yazarlar hisse senedi piyasasının işsizlik oranının açıklandığ1 günlerdeki değişimini incelemişler, ayrıca faiz oranlarındaki değişimin gerçekleştiği günlerdeki etkiyi de inceleyerek iki durumu karşılaştırmışlardır. 1962-1995 dönemini kapsayan analizden elde edilen bulgular Amerikan ekonomisinde hisse senedi getirilerinin para politikası kararlarından daha fazla işsizlikle ilgili haberlere tepki verdiği sonucuna ulaşmışlardır.

Rigobon ve Sack (2001) para politikasının hisse senedi piyasası üzerindeki etkisini incelerken ilk etapta vektör otoregresyon yöntemini kullanmışlar, ancak daha sonra iki değişken arasındaki ilişkiyi içsellik problemi olabileceği gerekçesiyle farklı bir metodolojiyle (vaka çalısması yöntemiyle) yeniden ele almışardır. Tahminlerden elde edilen bulgular, hisse senedi getirilerinin para politikası kararlarında ortaya çıkan faiz oranı değişimlerine ters yönde tepki verdiği sonucunu ortaya koymuştur.

D’Amico ve Farka (2003) yukarıda ifade edilen çalışmalardan farklı olarak para politikası kararlarının açıklandığı andaki etkisini incelemişlerdir. Bu amaçla gelecek piyasalarında işlem gören menkul kıymetlerin, para politikası kararı açıklanmadan 5 dakika önceki ve açıklandıktan beş dakika sonraki fiyatlarını baz almışlardır. Bu iki fiyat arasındaki fark politika şoku olarak tanımlanmıştır. Daha sonra ise bu şokun hisse senedi getirilerinin değişimini incelemişlerdir. Çalsşmadan elde edilen bulgular, para politikası kararlarının ilk beş dakika içinde hisse senedi fiyatlarını yakından etkilediğini, ancak etkinin büyüklügünün diğer çalışmalardan elde edilen etkilerden görece daha küçük olduğunu göstermiştir. Craine ve Martin (2003) tarafindan yapilan çalışma ise hisse senetlerinin getirilerinde meydana gelen değişimi etkileyen faktörleri daha geniş yelpazede ele almayı hedeflemiştir. Çalsşma ilk etapta gözlemlenemeyen bileşenleri ele alan bir model oluşturmuş, modelin açıklayamadığı hata terimlerinin para politikası faiz kararlarına verdiği tepki 
anlık bazda ölçülmeye çalışılmıştır. Bu uygulama ile yazarlar, hisse senedi getirilerinde meydana gelen değişimin diğer değişkenlerce açıklanamayan kısmı üzerinde faiz oranındaki değişimin ilk bir saat içerisindeki etkisini ölçmeye çalışmışlardır. Elde edilen bulgular faiz oranı kararlarındaki değişimin ilk bir saat içinde hisse senetlerinin getirilerinin açıklanamayan kısmını açılama kabiliyetine sahip olduğunu göstermiştir. Andersson (2007) tarafindan yapılan çalışmada ise gün içi veriler kullanılmış, ayırıca Fed'in faiz kararlarının Euro Bölgesi’ndeki hisse senetlerinin getirileri üzerindeki etkisi ve ECB'nin faiz kararlarının Amerikan hisse senetlerinin getirileri üzerindeki etkileri de incelenmiştir. Elde edilen bulgular Amerikan faiz kararlarının hem Amerika hem de Avrupa'daki hisse senetlerinin getirilerini etkilediğini, ancak ECB'nin kararlarını Amerika'daki hisse senetlerinin getirilerini etkilemediğini tepit etmişlerdir.

\subsection{Beklenmeyen Para Politikası Kararlarının Hisse Senetlerinin Getiri Oranları Üzerindeki Etkisi}

Yukarıda da belirtilen çalısmaların temel odak noktası, para politikası kararlant ile hisse senetleri fiyatları arasındaki ilişki olmuştur. Ancak ilerleyen zamanda gerçekleştirilen çalışmalar beklenmeyen para politikası kararlarının etkilerinin hisse senetlerinin getirileri açısından daha önemli olabileceği varsayımından hareketle para politikası kararların beklenen ve beklenmeyen olarak ayırmayı yeğlemişlerdir. Edelberg ve Marshall (1996) tarafindan gerçekleştirilen çalışmada özellikle para politikasının beklenmeyen etkilerine odaklanılmışır. Yazarlar tarafindan oluşturulan beklenti modeli, daha sonra hisse senedi tepki fonksiyonuna entegre edilmiş ve para politikasına ilişkin beklentilerin etkileri incelenmiştir. Yazarlar çalsşmada beklenmeyen para politikası şoklarının beklenen şoklara nazaran hisse senedi fiyatları üzerinde daha büyük etkiler yarattığını göstermiştir. Bu sonuç iki farklı bulguya ulaşılmasını sağlamıştır. Birincisi, beklenen politika değişikliklerinin de hisse senedi piyasası üzerinde etki yaratması, ikincisi ise beklenmeyen politikaların beklenen politikalardan daha yüksek bir etkiye sahip olmasıdır. Birinci etki rasyonel bekleyişler hipotezinin hisse senedi piyasasında tam olarak geçerli olmadığını göstermiştir. Bilindiği gibi rasyonel bekleyişler hipotezine göre beklenen politika değişikliklerinin diğer piyasalardaki değişkenlerin fiyatları üzerinde herhangi bir etkisinin olmaması gerekmektedir. Oysa ki bu analiz, bir politika beklenen dahi olsa diğer piyasalar üzerinde bir etki ortaya çıkarabildiğini göstermiştir. İkincisi bulgu ise yine rasyonel bekleyişler hipoteziyle ilişkilidir. Bu çalışmanın ardından birçok çalışmada ekonomilerde kısmi rasyonel bekleyişlerin geçerli olduğu kabul edilmeye başlanmıştır. Beklenmeyen politikaların beklenen politikalardan daha yüksek bir etkiye sahip olması, insanların kısmen de olsa rasyonel karar verdiklerini ancak sürprizler karşısında çok da yapacak birşeyleri olmadığını göstermiştir. 
Kuttner (2001) de para politikası kararlarının hisse senetlerinin getirileri üzerindeki etkisini beklenen ve beklenmeyen para politikası kararlarına göre farklılık gösterebileceğini ifade etmiş, beklenmeyen politika sürprizlerinin gelecek faiz oranlarını, temettüleri ve getirileri daha keskin bir şekilde etkileyeceğini ifade etmiştir. Kuttner (2001) tarafından yapılan çalışmanın Edelberg ve Marshall (1996) tarafindan yapılan çalışmadan farkı beklenen politikalarda ortaya çıkmaktadır. Önceki yazarlar hem beklenen hem de beklenmeyen politikaların varlık piyasası üzerinde etkili olduğu sonucuna ulaşırlarken Kuttner (2001) beklenen politikaların özellikle tahvil piyasasında etkisiz olduğu bulgusuna ulaşmıştır. Bu bulgu, rasyonel bekleyişler hipotezinin geçerliliğini tekrar öne çıkarmıştır.

Beklenen ve beklenmeyen para politikası kararlarının etkilerine ilişkin bir diğer çalışma Bernanke ve Kuttner (2003) tarafindan yapılmıştır. Yazarlar diğer çalışmalardan farklı olarak politika faiz oranında meydana gelen beklenmeyen değişimi gelecek sözleşmelerinin (future contracts) fiyatlarında meydana gelen değişimden türetmişlerdir. Gelecek sözleşmelerinin fiyat1 merkez bankasının politika faiz kararından etkilendiği için bu sözleşmenin fiyatlarında meydana gelecek bir değişiklik ekonomide faiz oranı hedefinde sürpriz bir değişiklik yaşandığı anlamına gelecektir. Yazarlar, hisse senedi getirilerinin beklenen para politikası, beklenmeyen para politikası, işsizlik açıklamaları, ara dönem toplantılar ve yazılı yayınlar arasında en fazla beklenmeyen para politikası değişikliklerine tepki verdiği sonucuna ulaşmışlardır.

Türkiye ekonomisine ilişkin çalışma sayısı az olmasına karşın, konu çeşitli açılardan ele alınmıştır. Aktaş ve diğ. (2009) tarafından vaka analizi yöntemi kullanılarak Türkiye üzerine yapılan çalışmada 2004-2008 dönemi için para politikasinın 6, 12 ve 24 vadeli piyasa faizleri, IMKB 100 ve İMKB mali endeksleri, bazı risk primi göstergeleri ve döviz kurları üzerindeki etkisini incelemişlerdir. Çalışmadan elde edilen bulgular para politikasının hisse senedi piyasaları üzerinde negatif yönde etkili olduğu sonucuna ulaşmıştır.

Duran ve diğ. (2010) tarafindan yapılan çalışmada ise para politikasının hisse senedi fiyatları üzerindeki etkisi, hem eşanlılık hem de dişlanmış değişken sorunlarını dikkate alabilen değişen oynaklığa dayalı GMM yöntemi ile Türkiye için tahmin edilmiş ve tahmin sonuçları vaka çalışmasından elde edilen sonuçlar ile karşılaştırılmıştır. Bu yöntemlerin ikisi de, para politikası şoklarının oynaklığının para politikası kurulu (PPK) kararının açıklanması ile birlikte artmasına dayalıdır. Sonuçlar literatürdeki bulgular ile tutarlı bulunmuştur: politika faizlerindeki artışlar, hisse senedi flyatlarını sektörlere göre değişen oranlarda düşürmektedir. Özellikle mali sektör endeksinin diğer sektörlere göre politika faizlerinden daha fazla etkilenmesinin nedeni bu endekste yer alan firmaların faize duyarlılıklarının diğer firmalara göre daha 
yüksek olmasıdır. Çalısma Türkiye'de para politikasından sermaye piyasalarına bir aktarım olduğu konusunda oldukça güçlü bulgular sunmuştur.

Duran ve diğg. (2012) tarafindan yapılan bir diğer çalışma ise Türkiye'de para politikası kararlarının hisse senetlerinin ve hazine tahvillerinin getirileri üzerindeki etkisi incelenmiştir. Heteroskedastisite temelli GMM yönteminin kullanıldığı çalışmadan elde edilen bulgular para politikas1 aktarım mekanizmasının gelişmekte olan ülkelerdeki aktarım mekanizmaları ile paralelik gösterdiğini ifade etmiştir.

Faiz koridoru dönemini ele alan tek çalışma Küçükkocaoğlu ve diğ. (2013) tarafindan yapılmışır. Bu çalışmada yazarlar Türkiye'deki para politikası dönemini 2010 yllında yaşanan politika değişimini baz alarak geleneksel ve geleneksel olmayan para politikası dönemleri olarak ikiye ayırmışlardır. 2010 yllındaki değişiklik öncesi dönemi ifade eden geleneksel para politikası döneminde merkez bankası faiz kararlarının gerek İMKB genel endeksi gerekse de bireysel bankaların hisse senetlerinin getirileri üzerinde etkili olduğu sonucuna ulaşmışlardır. 2010 yılındaki değişimin sonrasındaki dönemi ifade eden geleneksel olmayan para politikası döneminde ise para politikası kararları ile hisse senetlerinin getirileri arasındaki bağın koptuğuna dair bulgu, bu çalışmanın en ilginç bulgusu olarak karşımıza çıkmaktadır. Yazarlar ilişkide meydana gelen zayıflamanın nedeni olarak para politikası karar günlerinin dışında diğer günlerin de varlık piyasaları açısından önemli günler haline dönüştüklerine dikkat çekmişlerdir.

Yukarıda ifade edilen çalışmaların tamamı, hisse senedi getirilerinde meydana gelen değişimlerin açıklayıcısı olarak para politikası kurulu kararlarını ve bu kararlarda alınan politika faizi değişikliklerini bağımsız değişken olarak kullanmaktadırlar. Oysa ki para politikası kararlarını beklenen ve beklenmeyen para politikası kararları olarak ayrıştırılıp incelenmesi, Türkiye ekonomisinde rasyonel bekleyişler hipotezinin geçerliliğinin test edilmesine de imkân verecektir. Bu amaçla bu çalışmada diğer çalışmalardan farklı olarak TCMB'nin PPK toplantılarında alınan politika faizi kararları beklenen ve beklenmeyen olarak iki parçaya ayrıştırılmış ve bu iki değişsenin hisse senetlerinin getirileri üzerindeki etkileri incelenmiştir. Bu nedenle çalışmanın literatürdeki önemli bir boşluğu doldurma potansiyeline sahip olduğu görüşmeltedir.

\section{Veri Seti}

Veriler Ocak 2005 - Aralık 2015 dönemini kapsamaktadır. Çalışmada kullanılan beklenmeyen para politikası şoklarına ilişkin veriler, üç aylık Türk lirası LIBOR gelecek sözleşmelerinden türetilmiştir. Eğer PPK tarafindan alınan faiz kararı beklenen bir politika ise bu sözleşmelere ilişkin getiri oranında herhangi bir değişiklik olmayacaktır. Ancak PPK kararlarından hemen sonra bu sözleşmelerin getiri oranında bir değişiklik meydana gelirse, 
PPK tarafından alınan kararların beklenmeyen para politikası kararları olduğu söylenebilir. Hisse senetlerine ilişkin olarak ise Borsa İstanbul (BİST) Tüm Endeksi , BİST 100 Endeksi ve alt sektörlerden hizmet endeksi, mali endeks, sınai endeks, teknoloji endeksi ele alınmıştır. Örneklem dönemi, toplam 132 adet faiz kararı dönemini kapsamaktadır.

Çalışmada hisse senetlerinin getirisi, t zamanında i sektörüne ait olan endeks değerinin günün kapanışındaki değerinin doğal logaritmasının birinci farkı alınarak hesaplanmıştır. Denklem 1'de yer alan $r_{t}$ hisse senedinin PPK toplantı gününün kapanışındaki getiri oranını, ln doğal logaritmayı, $\mathrm{S}$ ise hisse senetini temsil etmektedir.

$$
r_{t}=100 *\left(\ln S_{t}-\ln S_{t-1}\right)
$$

Beklenmeyen faiz oranı değişikliklerini elde edebilmek için PPK toplantısı sonrasında ortaya çıkabilecek faiz şokunun elde edilmesi gerekmektedir. Bu faiz şoku $\Delta \mathrm{i}_{\mathrm{t}}^{\mathrm{u}}$ şeklinde gösterilir. ${ }^{3}$ Faiz şokunun elde edilmesinde yukarıda da belirtildiği gibi üç aylık Türk lirası LİBOR gelecek sözleşmelerinden yararlanılmıştır. Denklem 2'de üç aylık Türk lirası gelecek sözleşmelerinin faiz oranında meydana gelen değişimin, ay sonunda sona erecek olan sözleşmenin örtük gelecek oranında (f) (100 eksi sözleşmenin gelecekteki fiyatında) meydana gelen değissimden türetildiği ifade edilmektedir.

$$
\Delta i_{t}^{u}=f_{t}-f_{t-1}
$$

Bu durumda beklenen para politikası şoku, politika faiz oranında meydana gelen değişim ile üç aylık Türk lirası LIBOR gelecek sözleşmelerinin faiz oranında meydana gelen değişim arasındaki fark biçiminde tanımlanabilir. Denklem 3, beklenen para politikası şokuna $\left(\Delta \mathrm{i}_{\mathrm{t}}^{\mathrm{e}}\right)$ ilişkin hesaplamanın nasıl yapıldı̆̆ını göstermektedir.

$$
\Delta i_{t}^{e}=\Delta i_{t}-\Delta i_{t}^{u}
$$

\section{Yöntem ve Model}

Çalışmada Edelberg ve Marshall (1996) tarafindan yapılan çalışmayı takiben kullanilacak model, hem beklenen $\left(\Delta \mathrm{i}_{\mathrm{t}}^{\mathrm{e}}\right)$ hem de beklenmeyen $\left(\Delta \mathrm{i}_{\mathrm{t}}^{\mathrm{u}}\right)$ para politikası şoklarının hisse senetlerinin getirileri $\left(r_{t}\right)$ üzerindeki etkilerini

\footnotetext{
${ }^{3}$ Literatürde beklenen ve beklenmeyen faiz oranının hesaplanmasına dönük çok sayıda yöntem mevcuttur. Her ne kadar farklı yöntemler mevcut olsa da bu yöntemlerden en çok kabul göreni Edelberg ve Marshall (1996) tarafindan geliştirilen yöntem olmuş. Biz de çalışmamızda bu yaklaşımı takiben adı geçen yazarlar tarafindan kullanılan yöntemi benimsemiş bulunmaktayı.
} 
incelemeye imkan vermektedir. Denklem 4'ün sonunda yer alan hata terimi $\left(\varepsilon_{t}\right)$ para politikası kararları dışında hisse senetlerinin getirileri üzerinde etkili olan diğer faktörleri vermektedir.

$$
r_{t}=\alpha+\beta \Delta i_{t}^{e}+\delta \Delta i_{t}^{u}+\varepsilon_{t}
$$

En küçük kareler (OLS) ile yapılan tahminden elde edilen bulgular hem beklenen hem de beklenmeyen para politikası kararlarının istatistiksel olarak anlamsız olduğunu göstermiştir. Bu durum bizi beklenen ve beklenmeyen para politikası kararlarının hisse senetleri fiyatları üzerinde etkili olmadığını sonucuna götürmüştür. Ancak konunun teorik olarak çok güçlü olması ve literatürdeki çalışmaların iki değişken arasında güçlü ilişkiler bulmuş olması sebebiyle çalışmanın derinleştirilerek ilerletilmesi karar verilmiştir. Nitekim Denklem 4 dikkate alınarak yapılan tahminden elde edilen bulgular, artıkların hem heteroskedastisite hem de seri korelasyon içerdiğini, bu nedenle de elde edilen katsayıların sapmalı olduğunu işaret etmiştir. Çıplak gözle incelendiğinde verilerin küresel finansal kriz döneminde uç değerlere (outlier) sahip olduğu görülmüştür. Katsayıların anlamsız çıkmasının olası bir nedeni bu uç değerler olabileceği için modele küresel finansal kriz kukla değişkeni (GFC) eklenmiş ve model yeniden tahmin edilmiştir. Yeniden tahmin edilen model Denklem 5'te sunulmuştur. Anılan dönemde GFC değişkeni 1, diğer dönemlerde ise 0 değerini almıştır.

Tablo 1: Hisse senedi getirisine ilişkin OLS tahmin sonuçları

\begin{tabular}{|c|c|}
\hline Değişken & Model 1 (Eşitlik 4) \\
\hline$\alpha$ & $-0.21(2.0)^{*}$ \\
\hline$\Delta i_{t}^{e}$ & $-2.82(-1.01)$ \\
\hline$\Delta i_{t}^{u}$ & $2.99(1.05)$ \\
\hline Düzeltilmiş $R^{2}$ & 0.32 \\
\hline$Q(1)$ & $4.955^{* * *}$ \\
\hline$Q(1)$ & $11.254^{* * *}$ \\
\hline BPG F Testi & $4.255^{* *}$ \\
\hline DW Testi & $1.98^{* * *}$ \\
\hline \multicolumn{2}{|c|}{ 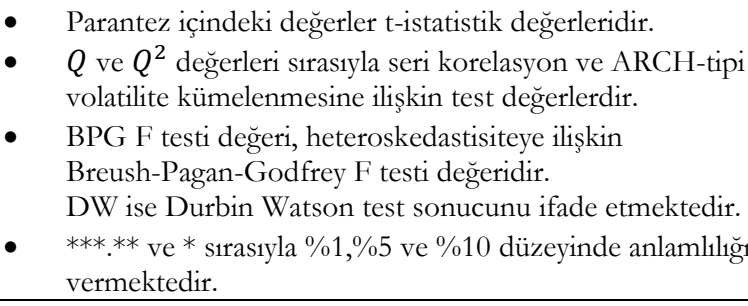 } \\
\hline
\end{tabular}




$$
r_{t}=\alpha+\beta \Delta i_{t}^{e}+\delta \Delta i_{t}^{u}+\gamma G F C+\varepsilon_{t}
$$

Tablo 2'den elde edilen değerler incelendiğinde düzeltilmiş $\mathrm{R}$ kare değerinde önemli ölçüde bir artıs meydana geldiği görülmektedir. Bu bulgu modeldeki değişkenlerin modeli açıklama gücünün arttığ1 şeklinde yorumlanabilir. Ayrica hata terimlerinin heteroskedastisite ve seri korelasyon problemlerinden kurtuldukları da görülmektedir. Anlamll1ık derecesi yüksek olan kukla değişken bir kenara bırakıldığında modeldeki değişkenlerden sadece bir tanesinin \%10 düzeyinde anlamlı olduğu göze çarpmaktadır: beklenmeyen faiz oranı değişiklikleri. Buna göre beklenmeyen faiz oranında meydana gelecek $\% 1^{\prime}$ lik bir artıs, hisse senetlerinin getirilerinin \%5.6 azalmasına neden olmaktadır. Beklenen faiz oranı değişiklikleri ise istatistiksel olarak anlamsız tespit edilmiştir. Beklenmeyen faiz oranı değişikliklerinin katsayısının negatif değer alması, PPK toplantısına ilişkin faiz beklentileri ile hisse senetlerinin fiyatları arasında ters yönlü bir ilişkinin olduğunu göstermiştir.

Tablo 2: Hisse senedi getirisine ilişkin OLS tahmin sonuçlan (Küresel Kriz Dahil)

\begin{tabular}{|c|c|}
\hline Değişken & Model 2 (Eşitlik 5) \\
\hline $\begin{array}{c}\alpha \\
\Delta i_{t}^{e} \\
\Delta i_{t}^{u} \\
G F C\end{array}$ & $\begin{array}{c}-0.15(1.55) \\
-4.03(-7.11)^{*} \\
-3.22(1.41) \\
-5.6(6.48)^{* * *}\end{array}$ \\
\hline $\begin{array}{c}\text { Düzeltilmiş } R^{2} \\
Q(1) \\
Q^{2}(1) \\
\text { BPG F Test } \\
\text { DW Testi }\end{array}$ & $\begin{array}{c}0.39 \\
0.085 \\
0.214 \\
0.554 \\
1.22\end{array}$ \\
\hline \multicolumn{2}{|c|}{$\begin{array}{ll}\text { - } & \text { Parantez içindeki değerler t-istatistik değerleridir. } \\
\text { - } & Q \text { ve } Q^{2} \text { değerleri sırasılla seri korelasyon ve ARCH-tipi } \\
\text { volatilite kümelenmesine ilişkin test değerlerdir. } \\
\text { - } \quad \text { BPG F testi değeri, heteroskedastisiteye ilişkin } \\
\text { Breush-Pagan-Godfrey F testi değeridir. } \\
\text { DW ise Durbin Watson test sonucunu ifade etmektedir. } \\
\text { - } * * * * * * \text { ve } * \text { sirasılyla } \% 1, \% 5 \text { ve } \% 10 \text { düzeyinde anlamlllğ } 1 \\
\text { vermektedir. }\end{array}$} \\
\hline
\end{tabular}


Tahmin edilen model her ne kadar sadece beklenmeyen faiz oran değişikliklerinin hisse senetlerinin fiyatları üzerinde anlamlı bir etkiye neden olduğunu göstermiş olsa da beklenen faiz oranı değişikliklerinin de hisse senetleri fiyatları açısından önemli olduğuna dair çok sayıda çalışma bulunmaktadır. Bu nedenle çalışmamızda revizyona gidilmiş ve küresel finansal krizin beklenen faiz değişiklikleri üzerinde etkili olup olmadığını test etmek için Denklem 5'teki modelde yer alan beklenen faiz oranı değişiklikleri değişkeni ile küresel finansal kriz kukla değişkeni çarpilarak yeni bir model oluşturulmuştur. Benzer bir şekilde beklenmeyen faiz oranı değişkeni de aynı şekilde çarpılarak modele eklenmiştir. Bu yeni model Denklem 6'da sunulmuştur.

$$
r_{t}=\alpha+\left(\beta^{e}+\gamma G F C\right) \Delta i_{t}^{e}+\left(\beta^{u}+\gamma G F C\right) \Delta i_{t}^{u}+\gamma G F C+\varepsilon_{t}
$$

Tablo 3'ten elde edilen bulgular, ilginç ve yeni sonuçlar önermektedir. Modelde düzeltilmiş $\mathrm{R}$ kare değeri $\% 55$ 'in üzerine çıkmaktadır ve tüm değişkenler istatistiksel olarak $\% 5$ düzeyinde anlamlı çıkmaktadır. Bir diğer deyişle hisse senetleri fiyatları hem beklenen hem de beklenmeyen para politikası şoklarına negatf yönlü tepki vermektedir. Beklenen faiz oranında meydana gelecek \%1'lik bir artıs hisse senetlerinin getiri oranlarının \%2.99 azalmasına neden olmaktadır. Benzer bir şekilde beklenmeyen faiz kararlarının da hisse senetlerinin getiri oranlarını \%6.55 azalttığ1 tespit edilmiştir. Bu bulgular Türkiye ekonomisine ilişkin literatürdeki çalışmaların bulgularıyla benzerlik arz etmektedir (her ne kadar çalışmalar para politikası kararlarını beklenen ve beklenmeyen olarak ayrıştırmasa da elde edilen tepki değerlerinin ortalamasının literatürdeki tepki değerlerinin ortalamasına yakın seyrettiği gözlemlenmiştir).

Tablo 3: Hisse senedi getirisine ilişkin OLS tahmin sonuçları (Küresel Kriz Hariç)

\begin{tabular}{c|c}
\hline Değişken & Model 3 (Eşitlik 6) \\
\hline$\alpha$ & $-0.12(1.45)^{* *}$ \\
$\Delta i_{t}^{e}$ & $-2.99(-3.11)^{* * *}$ \\
$\Delta i_{t}^{u}$ & $-6.55(2.22)^{* * *}$ \\
$G F C$ & $-5.34(4.94)^{* * *}$ \\
$\left(\beta^{e}+\gamma G F C\right) \Delta i_{t}^{e}$ & $13.92(2.91)^{* *}$ \\
$\left(\beta^{u}+\gamma G F C\right) \Delta i_{t}^{u}$ & $12.20(2.24)^{* *}$ \\
Düzeltilmiş $R^{2}$ & \\
$Q(1)$ & 0.57 \\
$Q^{2}(1)$ & 0.181 \\
BPG F Test & 0.225 \\
\end{tabular}




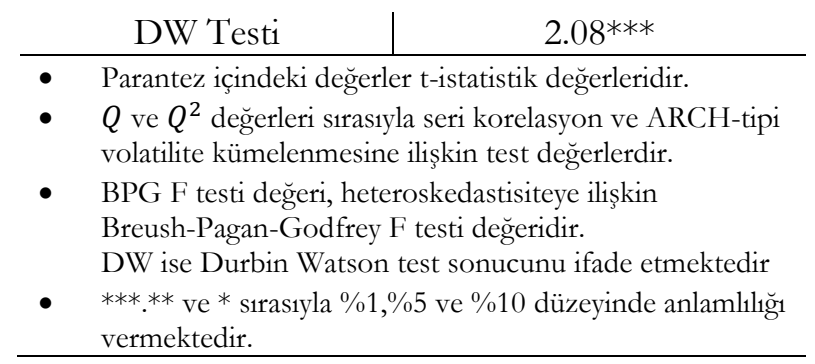

\section{Sonuç}

Finansal veriler içerisinde yer alan varlık fiyatları gerek ekonominin parasal kesiminin davranışının izlenmesi, gerekse de ekonominin reel kesiminde meydana gelen değişimlerin izlenmesi açısından oldukça yararlı bilgiler sunmaktadır. Varlık fiyatlarını etkileme potansiyeline sahip çok sayıda ekonomik değişken olsa da politika bazındaki değişkenlerin etkilerinin incelenmesi, ekonominin yönetiminin anlaşılabilmesi açısından son derece önemlidir. Bu amaçla çalışmada Türkiye Cumhuriyet Merkez Bankası'nın (TCMB) beklenen ve beklenmeyen para politikası kararlarının Borsa İstanbul'da (BİST) işlem gören hisse senetlerinin fiyatları üzerindeki etkileri incelenmiştir.

Para politikası kararlarının hisse senetlerinin getiri oranları üzerindeki etkileri incelenirken değişik içeriğe sahip modeller kullanılmıştır. Modellerin çoğu açıklayıcı değişken olarak doğrudan politika faizini kullanmışlar, ancak bu değişkenin tanımlanmasında değişik frekans değerlerinden (günlük, saatlik, 5 dakikalık vs) yararlanmışlardır. Bizim çalışmamızda ise frekans değerinden ziyade açılanan politika faizinin beklenen ve beklenmeyen politika faizi olmak üzere iki bileşene ayrılması ve bu iki değişkenin etkisinin ayrı ayrı incelenmesi hedeflenmiştir. Bu amaçla üç aylık Türk lirası LIBOR gelecek sözleşmelerinden hareket edilerek beklenmeyen faiz oranı serisi türeilmiştir. Bu seriden hareket edilerek de beklenen faiz oranı değişkeni elde edilmiştir.

Çalışmada tahminler en küçük kareler (OLS) yöntemi ile gerçekleştirilmiştir. Toplam üç model oluşturulmuştur. Birinci modelde beklenen ve beklenmeyen faiz oranı değişkenlerinin hisse senetlerinin fiyatları üzerindeki etkileri incelenmiştir. Elde edilen bulgular hem beklenen hem de beklenmeyen para politikası kararlarının istatistiksel olarak anlamsız olduğunu göstermiştir. Ancak konunun teorik olarak çok güçlü olması ve literatürdeki çalışmaların iki değişken arasında güçlü ilişkiler bulmuş olması sebebiyle modele kukla değişken eklenmesi kararlaştırılmıştır. Nitekim veriler çıplak gözle incelendiğinde küresel finansal kriz döneminde uç değerlerin ortaya çıktığ1 görülmüştür. Küresel finansal kriz kukla değişkeni ile model yeniden tahmin edildiğinde modeldeki değişkenlerden sadece bir tanesinin \%10 düzeyinde anlamlı olduğu göze çarpmıştır: beklenmeyen faiz oranı. Buna göre 
beklenmeyen faiz oranında meydana gelecek \%1'lik bir artışn, hisse senetlerinin getirilerinin \%5.6 azalmasına neden olduğu tespit edilmiştir. Beklenen faiz oranı değişiklikleri ise istatistiksel olarak anlamsız tespit edilmiştir. Beklenmeyen faiz oranı değişikliklerinin katsayısının negatif değer alması, PPK toplantısına ilişkin faiz beklentileri ile hisse senetlerinin fiyatları arasında ters yönlü bir ilişkinin olduğunu göstermiştir.

Tahmin edilen model her ne kadar sadece beklenmeyen faiz oran değişikliklerinin hisse senetlerinin fiyatları üzerinde anlamlı bir etkiye neden olduğunu göstermiş olsa da beklenen faiz oranı değişikliklerinin de hisse senetleri fiyatları açısından önemli olduğuna dair çok sayıda çalışma bulunduğundan çalışmada tekrar revizyona gidilmiş ve küresel finansal krizin beklenen faiz değişiklikleri üzerinde etkili olup olmadığını test etmek için modelde yer alan beklenen ve beklenmeyen faiz oranı değişkenleri ile küresel finansal kriz kukla değişkeni ayrı ayrı çarpılarak yeni bir model oluşturulmuştur. Elde edilen bulgular, tüm değişkenler istatistiksel olarak anlamlı çıktı̆ıını göstermiş, hisse senetleri fiyatları ile hem beklenen hem de beklenmeyen para politikası şokları arasında negatif bir ilişki olduğu tespit edilmiştir.

Son modelden elde edilen sonuçlar iki farklı bulguya ulaşılmasına imkân sağlamıştır. Birincisi, beklenen politika değişikliklerinin de hisse senedi piyasası üzerinde etki yaratması, ikincisi ise beklenmeyen politikaların beklenen politikalardan daha yüksek bir etkiye sahip olmasıdır. Birinci etki rasyonel bekleyişler hipotezinin Türkiye'de hisse senedi piyasasında tam olarak geçerli olmadığını göstermiştir. Rasyonel bekleyişler hipotezine göre beklenen politika değişikliklerinin diğer piyasalardaki değişkenlerin fiyatları üzerinde herhangi bir etkisinin olmaması gerekmektedir. Oysa ki bu analiz, bir politika beklenen dahi olsa diğer piyasalar üzerinde bir etki ortaya çıkarabildiğini göstermiştir. İkincisi bulgu ise yine rasyonel bekleyişler hipoteziyle ilişkilidir. Beklenmeyen politikaların beklenen politikalardan daha yüksek bir etkiye sahip olmasi, insanların kısmen de olsa rasyonel karar verdiklerini ancak sürprizler karşısında çok da yapacak birşeyleri olmadığını göstermiştir. Bu bulguların Edeblerg ve Marshall (1996), Bernanke ve Kuttner (2005) ve Bredin ve diğerleri (2007) tarafından yapılan çarlışmalarla benzer özellikler gösterdiğinin altı da ayrıca çizilmelidir.

Enflasyon hedeflemesi rejiminde hisse senedi piyasası ve döviz piyasasında meydana gelen dalgalanmaların etkilerinin telafisinde politika faizi merkez bankaları tarafindan yoğun bir şekilde kullanılmaktadır. Merkez bankaları politika faizinde indirime giderken kademeli bir azalışa gitmekte ve bu azalışın varlık piyasası üzerindeki etkisi de kademeli olmaktadır. Varlık piyasasında meydana gelen olumsuz şoklarda ise faiz oranlarındaki artış kararına ilişkin tartışmalar oldukça sıcaktır. Bir görüş faiz artışın kademeli yapılması gerektiğine yönelik fikre sahipken diğer görüş politika faizindeki artışın ani ve 
hızlı olması gerektiği fikrine sahiptir. Yukarıdaki verilerden hareketle Türkiye'de merkez bankasının politika faizinde beklenmeyen bir artışa gitmesinin varlık piyasası üzerinde daha etkili olduğu sonucuna ulaşılmaktadır. $\mathrm{Bu}$ bulgu bize politika önermesi olarak varlık piyasasındaki dalgalanmaların giderilmesinde TCMB'nin ani ve hızlı artış yolunu tercih etmesinin daha uygun olduğunu işaret etmektedir. 


\section{Kaynakça}

Andersson, M. (2007). Using Intraday Data to Gauge Financial Market Responses to FED and ECB Monetary Policy Decisions, ECB Working Paper, No. 726

Bernanke, B. \& Kuttner, K. (2005). "What Explains the Stock Market's Reaction to Federal Reserve Policy?", The Journal of Finance 60(3)

Bohl, M.T., Siklos, P.L. \& Sondermann, D. (2008). "European Stock Markets and the ECB's Monetary Policy Surprises", International Finance 11(2)

Boyd, J.H., Jagannathan, R. \& Hu, J. (2001). “The Stock Market's Reaction to Unemployment News: Why Bad News Is Usually Good For Stocks", NBER Working Paper 8092

Craine, R. \& Martin, V. (2003). "Monetary Policy Shocks and Security Market Responses", Unpublished Manuscript, University of California at Berkeley

Duran, M., Özcan, G., Özlü, P. \& Ünalmış, D. (2012) “Measuring the impact of monetary policy on asset prices in Turkey", Economics Letters 114

Duran, M., Özlü, P. \& Ünalmıs, D. (2010) “TCMB Faiz Kararlarının Hisse Senedi Piyasaları Üzerine Etkisi”, Central Bank Review, 10(2)

Edelberg, W., \& Marshall, D. (1996). Monetary policy shocks and long-term interest rates. Federal Reserve Bank of Chicago Economic Perspectives, 20, 2-17.

Fair, R.C. (2006). "Events That Shook the Market", The Journal of Business 75(2)

Kuttner, K.N. (2001). "Monetary Policy Surprises and Interest Rates: Evidence from the Fed Funds Futures Market", Journal of Monetary Economics, 47 (3)

Küçükkocaoğlu, G., Ünalmış, D. \& Ünalmış, İ. (2013). “How do banks' stock returns respond to monetary policy committee announcements in Turkey? Evidence from traditional versus new monetary policy episodes", Economic Modelling 35

Rigobon, R. \& Sack, B. (2002). "The Impact of Monetary Policy on Asset Prices“. Finance and Economics Discussion Series 2002-4. Board of Governors of the Federal Reserve System

Rigobon, R., \& Sack, B. (2003). "Measuring the Reaction of Monetary Policy to the Stock Market", Quarterly Journal of Economics , 118 